Dikirim: 21 Oktober 2015 Diterbitkan: 1 Mei 2016

\section{Analisis laik sehat dan kualitas mikrobiologis air minum isi ulang di Kecamatan Ligung, Majalengka}

\author{
Feasibility analysis of health and quality of microbiology \\ refill drinking water in in Ligung District, Majalengka
}

Iman Iman ${ }^{1}$, Titik Nuryastuti ${ }^{2}$, Lucky Herawati ${ }^{3}$

\begin{abstract}
Purpose: The purpose of this study was to explore the relationship of feasibility analysis of health indicators with the microbiological quality of refill drinking water. Methods: The study used a descriptive design with a cross-sectional analytic approach. The dependent variable was the microbiological quality of refill drinking water. The independent variables were the following health indicators: raw water quality, equipment and processing method, operator behavior, and sanitation of depot building. Results: There were significant correlations between variables of health indicator, equipment and processing method with E.coli microbiological quality. There was no significant correlation between quality of raw water, behavior of the operator, and sanitation buildings with microbiological quality. Conclusion: Almost fifty percent of DAMIU refill drinking water is not qualified for microbiological quality of coliform and microbiological quality of Escheria coli. The most dominant factors affecting microbiological quality of drinking water refills are equipment and processing.
\end{abstract}

Keywords: feasibility analysis; refill drinking water; microbiological quality

\footnotetext{
${ }^{1}$ Departemen Perilaku Kesehatan, Lingkungan dan Kedokteran Sosial, Fakultas Kedokteran, Universitas Gadjah Mada (Email: iman2014@mail.ugm.ac.id)

${ }^{2}$ Departemen Mikrobiologi, Fakultas Kedokteran, Universitas Gadjah Mada

${ }^{3}$ Poltekkes Kementerian Kesehatan, Yogyakarta
} 


\section{PENDAHULUAN}

Air merupakan materi esensial dalam kebutuhan manusia, karena air merupakan zat pembentuk tubuh manusia, 68\% dari tubuh manusia (1). Di daerah perkotaan, dalam hal pemenuhan kebutuhan air minum masyarakat mengkonsumsi air minum dalam kemasan (AMDK), karena praktis dan dianggap lebih higienis. Air minum dalam kemasan diproduksi oleh industri melalui proses otomatis dan disertai dengan pengujian kualitas sebelum diedarkan ke masyarakat. Lambat laun perkembangan air minum dalam kemasan berkembang pesat. Tetapi, makin lama harga air minum dalam kemasan lebih mahal dan hanya dapat dijangkau oleh golongan ekonomi menengah ke atas (2). Alternatif lain air minum yang diproduksi oleh depot air minum isi ulang (DAMIU). Kualitas air produksi DAMIU semakin menurun karena peralatan DAMIU yang mempunyai daya bunuh bakteri rendah atau operator belum mengetahui peralatan yang baik dan cara pemeliharaan dan pengawasan masih lemah (3). Hasil penelitian lain mengungkapkan bahwa faktor yang mempengaruhi kualitas mikrobiologi air minum isi ulang adalah perilaku pengelola dan sanitasi bangunan Depot air minum isi ulang (4).

Data profil Dinas Kesehatan Kabupaten Majalengka Tahun 2012, terdapat 415 sarana DAMIU yang sudah terdaftar. Hasil pemeriksaan mikrobiologi DAMIU yang memenuhi syarat pada triwulan I baru mencapai 104 DAMIU (44,83\%) dari 232 DAMIU yang diperiksa, triwulan II sebanyak 197 DAMIU (59,16\%) dari 333 DAMIU yang diperiksa, Triwulan III sebanyak 150 DAMIU (51,90\%) dari 289 DAMIU yang diperiksa dan triwulan IV sebanyak 181 DAMIU (54,68\%) dari 331 DAMIU yang diperiksa. Sarana yang memenuhi syarat selama empat triwulan berturut-turut sebanyak 14 DAMIU (3,37\%) dari 415 DAMIU yang terdaftar (5). Berdasarkan hasil evaluasi Puskesmas Ligung Tahun 2013, kualitas mikrobiologi air minum isi ulang yang ada di wilayah kerja Puskesmas Ligung yaitu 53,3\% dari 57 sarana memenuhi syarat dan sisanya $46,7 \%$ tidak memenuhi syarat (6). Oleh sebab itu, penelitian ini perlu dilakukan. Penelitian ini bertujuan untuk mengeksplorasi hubungan analisis kelayakan kesehatan dengan kualitas mikrobiologis air minum isi ulang.

\section{METODE}

Jenis penelitian ini adalah deskriptif analitik. Pendekatan yang digunakan adalah cross-sectional.
Variabel bebas adalah Laik sehat (kualitas air baku, peralatan dan proses pengolahan, perilaku operator dan sanitasi bangunan depot air minum isi ulang. Analisis bivariat dilakukan untuk mengetahui hubungan variabel bebas dengan variabel terikat. Analisis statistik bivariat dengan menggunakan chisquare, dengan $\alpha=0,005$. Analisis multivariat menggunakan regresi logistik untuk melihat variabel bebas mana yang memiliki pengaruh dominan terhadap variabel terikat.

\section{HASIL}

Tabel 1. Distribusi frekuensi hasil observasi variabel bebas

\begin{tabular}{lcccc}
\hline & \multicolumn{4}{c}{ Kategori } \\
\cline { 2 - 5 } Variabel & \multicolumn{3}{c}{ MS } & TMS \\
\cline { 2 - 5 } & Persentase & F & $\begin{array}{c}\text { Persentas } \\
\text { e (\%) }\end{array}$ \\
\hline $\begin{array}{l}\text { Kualitas Air Baku } \\
\begin{array}{l}\text { Peralatan dan } \\
\text { Proses }\end{array}\end{array}$ & 1 & 1,75 & 56 & 98,25 \\
$\begin{array}{l}\text { Pengolahan } \\
\begin{array}{l}\text { Perilaku } \\
\text { Operator }\end{array}\end{array}$ & 50,88 & 28 & 49,12 \\
$\begin{array}{l}\text { Sanitasi } \\
\text { Bangunan }\end{array}$ & 10 & 5,26 & 54 & 94,74 \\
\hline
\end{tabular}

Hasil pemeriksaan laboratorium terhadap kualitas mikrobiologi air minum isi ulang menunjukkanbahwa dari 57 DAMIU terdapat 31 DAMIU (54,39\%) belum memenuhi syarat Coliform dan 28 DAMIU $(49,12 \%)$ belum memenuhi syarat Escherichia coli. Kualitas mikrobiologi air minum isi ulang dapat dipengaruhi oleh beberapa faktor seperti air baku, jenis peralatan, pemeliharaan peralatan dan penanganan pengolahan dan pendistribusian (7).

Kualitas mikrobiologi air baku menunjukkan terdapat 56 DAMIU (98,25\%) Tidak Memenuhi Syarat (TMS) Coliform dan 54 DAMIU (94,74\%) Tidak memenuhi Syarat (TMS) Eschrichia coli. Air baku yang digunakan oleh depot air minum isi ulang berasal dari empat sumber PDAM Majalengka, Cikalahang Kuningan, Ciremai Water, Arrohmah Kuningan. Berdasarkan hasil observasi dan wawancara kepada pemilik DAMIU, ternyata banyak yang tidak memiliki bukti tertulis atau sertifikat asal air baku. Sehingga dari 57 DAMIU semuanya tidak bisa menunjukkan bukti tertulis atau sertfikat asal air baku (8).

Hasil observasi menunjukkan 29 DAMIU $(50,88 \%)$ termasuk kategori LS dan sisanya 28 DAMIU (49,12\%) termasuk kategori TLS. Kondisi Laik sehat sarana depot air minum isi ulang dipengaruhi oleh kualitas air baku, peralatan dan proses pengolahan dan sanitasi bangunan (9). 
Data kualitas air baku yang diperoleh berdasarkan hasil pemeriksaan laboratorium dan hasil observasi menggunakan format check list diperoleh hasil satu DAMIU (1,75\%) masuk dalam kategori memenuhi syarat (MS), 56 DAMIU (98,25\%) masuk dalam kategori tidak memenuhi syarat (TMS). Kualitas air baku dipengaruhi oleh bakterologis air baku, proses pengangkutan dan proses penyimpanan (10).

Dua puluh sembilan DAMIU (50,88\%) masuk dalam kategori Memenuhi Syarat (MS), 28 DAMIU (49,12\%) masuk dalam kategori Tidak Memenuhi Syarat (TMS). Berdasarkan hasil observasi di lapangan, diketahui peralatan dan proses pengolahan masih banyak yang kurang, diantaranya jumlah mikro filter, masa aktif, alat penunjuk tekanan, peralatan desinfeksi, dan masa pakai peralatan desinfeksi (10).

Distribusi frekuensi hasil observasi perilaku operator kemudian dikategorikan, diperoleh hasil 3 DAMIU (5,26\%) masuk dalam kategori Memenuhi Syarat (MS), 54 DAMIU (94,74\%) masuk dalam kategori Tidak Memenuhi Syarat (TMS). Hanya 3 operator yang dapat menunjukkan sertifikat penjamah makanan dan minuman. Operator DAMIU banyak yang tidak tahu kalau perlu adanya pelatihan tentang pelatihan penjamah makanan. Perilaku hidup bersih sehat operator meliputi tidak sambil makan atau minum saat bekerja dan tidak sambil merokok saat bekerja (10).

Berdasarkan Distribusi frekuensi hasil observasi sanitasi bangunan diperoleh hasil 10 DAMIU (17,54\%) masuk dalam kategori Memenuhi Syarat (MS), 47 DAMIU (82,46\%) masuk dalam kategori Tidak Memenhi Syarat (TMS). Berdasarkan hasil observasi di lapangan, diketahui Letak DAMIU banyak berada di daerah perumahan atau perkampungan, pertokoan, bahkan ada yang menjadi satu dengan usaha lain yang tidak berkaitan dengan produknya.

Tabel 1. Rekaptulasi analisis bivariat terhadap kualitas mikrobiologi air minum isi ulang

\begin{tabular}{|c|c|c|c|c|}
\hline \multirow{3}{*}{$\begin{array}{l}\text { Variabel } \\
\text { bebas }\end{array}$} & \multicolumn{4}{|c|}{ Variabel terikat } \\
\hline & \multicolumn{2}{|c|}{$\begin{array}{c}\text { Variabel } \\
\text { terikat } \\
\text { Coliform }\end{array}$} & \multicolumn{2}{|c|}{$\begin{array}{l}\text { Variabel terikat } \\
\text { Escherichia coli }\end{array}$} \\
\hline & $\mathbf{P}$ & $\begin{array}{l}\text { Fishers's } \\
\text { exact }\end{array}$ & $\mathbf{P}$ & $\begin{array}{c}\text { Fishers's } \\
\text { exact }\end{array}$ \\
\hline Laik sehat & 0.000 & 0.000 & 0.000 & 0.000 \\
\hline $\begin{array}{l}\text { Kualitas Air } \\
\text { Baku }\end{array}$ & 0.356 & 1,000 & 0,305 & 0,491 \\
\hline $\begin{array}{l}\text { Peralatan } \\
\text { dan Proses } \\
\text { Pengolahan }\end{array}$ & 0,000 & 0,000 & 0,000 & 0,000 \\
\hline $\begin{array}{l}\text { Prilaku } \\
\text { Operator }\end{array}$ & 0,452 & 0,587 & 0,532 & 0,611 \\
\hline $\begin{array}{l}\text { Sanitasi } \\
\text { Bangunan }\end{array}$ & 0,759 & 1,000 & 0,449 & 0,504 \\
\hline
\end{tabular}

\section{BAHASAN}

Penelitian ini menemukan hubungan signifikan antara Laik sehat dengan kualitas mikrobiologi Coliform air minum isi ulang. Analisis yang sama menunjukkan ada hubungan yang signifikan antara Laik sehat dengan kualitas mikrobiologi Escherichia coli air minum isi ulang. Hal ini menunjukkan bahwa proses Laik sehat mempunyai peranan penting terhadap kualitas mikrobiologi Coliform air minum isi ulang (8). Kualitas bakterilogis air minum isi ulang dipengaruhi oleh kondisi air baku, kondisi peralatan, proses pengolahan sanitasi bangunan, dan kepatuhan operator terhadap SOP yang telah ditentukan (8).

Analisis hubungan kualitas air baku dengan kualitas mikrobiologi air minum isi ualng dengan menggunakan fisher's exact (terdapat nilai expected kurang dari 5) menunjukkan tidak ada hubungan yang signifikan antara kualitas air baku dengan kualitas mikrobiologi Coliform air minum isi ulang. Analisis yang sama dilakukan untuk mengetahui hubungan antara kualitas air baku dengan kualitas mikrobiologi Escherichia coli menunjukkan tidak ada hubungan yang signifikan antara kualitas air baku dengan kualitas mikrobiologi Escherichia coli air minum isi ulang. Kondisi air baku berhubungan dengan kualitas mikrobiologi air minum isi ulang $(9,10,11)$.

Ada hubungan signifikan antara peralatan dan proses pengolahan dengan kualitas mikrobiologi Coliform air minum isi ulang. Analisis yang sama dilakukan menunjukkan ada hubungan yang signifikan antara peralatan dan proses pengolahan dengan kualitas mikrobiologi Escherichia coli air minum isi ulang. Proses filtrasi dan proses desinfeksi berhubungan dengan kualitas bakteriologis air minum isi ulang (11). Hasil analisis menunjukkan tidak ada hubungan signifikan antara perilaku operator dengan kualitas mikrobiologi Coliform air minum isi ulang. Analisis yang sama menunjukkan tidak ada hubungan signifikan antara perilaku operator dengan kualitas mikrobiologi Escherichia coli air minum isi ulang. Kepatuhan operator terhadap SOP dan hygiene operator berhubungan dengan kualitas mikrobiologi air minum isi ulang (11).

Analisis fisher's exact menunjukkan tidak ada hubungan signifikan antara sanitasi bangunan dengan kualitas mikrobiologi Coliform air minum isi ulang. Analisis yang sama menunjukkan tidak ada hubungan signifikan antara sanitasi bangunan dengan kualitas mikrobiologi Escherichia coli air minum isi ulang. Tidak ada hubungan antara sanitasi DAMIU dengan 
kualitas mikrobiologi air minum isi ulang (11). Hasil analisis regresi logistik menunjukkan bahwa sub variabel laik sehat yang berhubungan dengan kualitas mikrobiologi air minum isi ulang adalah peralatan dan proses pengolahan. Probabilitas sub variabel peralatan dan proses pengolahan dengan kategori memenuhi syarat untuk mempunyai kualitas mikrobiologi air minum isi ulang yang memenuhi syarat adalah $77 \%$.

\section{SIMPULAN}

Hampir lima puluh persen air minum isi ulang DAMIU belum memenuhi syarat kualitas mikrobiologi coliform dan kualitas mikrobiologi Escheria coli. Faktor yang paling dominan memengaruhi kualitas mikrobiologi air minum isi ulang adalah peralatan dan proses pengolahan.

Bagi UPTD puskesmas Ligung diharapkan lebih memperhatikan peralatan dan proses pengolahan air minum isi ulang dan meningkatkan pengawasan terhadap sumber air baku yang digunakan.

Bagi pengelola air minum isi ulang disarankan untuk lebih memperhatikan pemenuhan standar pengelolaan air isi ulang seperti pemeriksaan dan pengelolaan peralatan dan jumlah filter yang digunakan. Selain itu, dihimbau agar tidak mencampur kegiatan usaha air isi ulang dengan usaha lain, karena dapat meningkatkan risiko kontaminasi.

Bagi operator air isi ulang, disarankan untuk mengenakan pakaian yang bersih, tidak makan atau minum, tidak meludah dan merokok ketika sedang bekerja.

\footnotetext{
Abstrak

Tujuan: Tujuan dari penelitian ini adalah untuk mengeksplorasi hubungan analisis kelayakan kesehatan dengan kualitas mikrobiologis air minum isi ulang. Metode: Jenis penelitian adalah deskriptif analitik dengan pendekatan cross sectional. Variabel terikat adalah kualitas mikrobiologi air minum isi ulang. Variabel bebas adalah laik sehat dan sub variabel: kualitas air baku, peralatan dan proses pengolahan, perilaku operator, dan sanitasi bangunan depot air minum isi ulang. Hasil: Ada hubungan yang signifikan antara indikator kesehatan variabel, peralatan, dan metode pengolahan dengan kualitas mikrobiologi E.coli. Tidak ada hubungan yang signifikan antara kualitas air baku, perilaku operator, dan bangunan sanitasi dengan kualitas mikrobiologis. Simpulan: Hampir lima puluh persen air minum isi ulang DAMIU belum memenuhi syarat kualitas mikrobiologi coliform dan kualitas mikro-
}

biologi Escheria coli. Faktor laik sehat yang paling dominan mempengaruhi kualitas mikrobiologi air minum isi ulang adalah peralatan dan proses pengolahan.

Kata kunci: depot air minum; kualitas mikrobiologi

\section{PUSTAKA}

1. Purwana. Pedoman dan pengawasan Higiene Sanitasi Depot Air Minum. Jakarta; 2003.

2. Rahayu CS, Setiani O, Nurjazuli N. Faktor Risiko Pencemaran Mikrobiologi pada Air Minum Isi Ulang di Kabupaten Tegal. J Kesehatan Lingkungan Indonesia. 2013 Dec 18;12(1):1-9.

3. Munandar AH. Modul Pelatihan Pemantauan Kualitas Kesehatan Lingkungan (On Site Rapid Assesment). Jakarta; 2012.

4. Suprihatin B, Adriyani R. Higiene sanitasi depot air minum isi ulang di Kecamatan Tanjung Redep Kabupaten Berau Kalimantan Timur. J Kesehat Lingkung. 2008;4(2).

5. Majalengka DKK. Profil Kesehatan Kabupaten Majalengka. Majalengka; 2013.

6. Puskesmas Lingung. Evaluasi Puskesmas Ligung Tahun 2013. Majalengka; 2013.

7. Athena, Sukar, Hendro, Anwar. Pengaruh pengolahan air di depot air minum isi ulang dalam menormalkan derajat keasaman. Media Penelit dan Pengemb Kesehaan. 2005;15(2).

8. Dirjen PP \& PL Kementerian Kesehatan RI. Pedoman Pelaksanaan Penyelenggaraan Hygiene Sanitasi Depot Air Minum. Jakarta; 2010.

9. Saleh R, Setiani O, Nurjazuli N. Efektivitas Unit Pengolahan Air di Depot Air Minum Isi Ulang (DAMIU) Dalam Menurunkan Kadar Logam (Fe, Mn) dan Mikroba di Kota Pekalongan. J Kesehat Lingkung. 2013 Dec 18;12(1):75-81.

10. Asfawi S. Faktor yang Berhubungan dengan Kualitas Mikrobiologi Air Minum Isi Ulang pada Tingkat Produsen di Kota Semarang Tahun 2004. Universitas Negeri Diponegoro; 2004.

11. Mirza MN. Hygiene Sanitasi dan jumlah Coliform air minum. Kesmas. 2014;9(2). 